\title{
DETEKSI DINI PERTUMBUHAN DAN PERKEMBANGAN ANAK USIA DINI DI PESANTREN TAPAK SUNAN JAKARTA TIMUR TAHUN 2019
}

\author{
Vivi Silawati, Nurpadilah, Surtini \\ Fakultas Ilmu Kesehatan, Universitas Nasional, Jakarta \\ vivi.sila@civitas.unas.ac.id
}

\begin{abstract}
This community service activity is a routine activity carried out by lecturers by involving students in the activity. This activity aims to change attitudes both in terms of Cognitive, Affective and Conative of parents and teachers, the methods used are lectures, simulations and questions and answers. The results of this activity were all participants very orderly listening to the exposure to the material and were enthusiastic when asking and answering questions and they said this activity was very useful to increase their knowledge and awareness of the development and growth of children who are not appropriate.
\end{abstract}

Keywords: Detection, Growth and Development, Toddler

\section{Abstrak}

Kegiatan pengabdian masyarakat ini merupakan kegiatan rutin yang dilakukan oleh dosen dengan mengikutsertakan mahasiswa dalam kegiatan tersebut. Kegiatan ini bertujuan untuk merubah sikap baik dari segi Kognitif, Afektif dan Konatif dari orang tua dan guru, metode yang digunakan adalah ceramah, simulasi dan tanya jawab. Hasil dari kegiatan ini semua peserta sangat tertib mendengarkan paparan materi dan antusias saat bertanya maupun menjawab pertanyaan dan mereka mengatakan kegiatan ini sangat bermanfaat untuk meningkatkan pengetahuan dan kewaspadaan mereka terhadap perkembangan dan pertumbuhan anak yang tidak sesuai.

Kata Kunci: Deteksi, Tumbuh Kembang, Balita

\section{Pendahuluan}

Pemantauan pertumbuhan dan perkembangan balita menjadi perhatian bagi semua negara khususnya Indonesia, perhatian terhadap kesehatan ibu dan anak telah menjadi perhatian pemerintah Indonesia dengan diterapkannya pelayanan kesehatan ibu dan anak sampai kepada lapisan masyarakat dan keluarga. Pemantauan pertumbuhan, perkembangan dan gangguan tumbuh kembang anak diatur dalam PP nomor 66 tahun 2014 yang diatur dalam pasal 2 "Pemantauan Pertumbuhan, Perkembangan, dan Gangguan Tumbuh Kembang Anak merupakan acuan bagi tenaga kesehatan yang bekerja pada fasilitas pelayanan kesehatan dasar/primer, kelompok profesi, tenaga pendidik, petugas lapangan Keluarga Berencana, petugas sosial yang terkait dengan pembinaan tumbuh kembang anak, organisasi profesi dan pemangku kepentingan terkait pertumbuhan, perkembangan, dan gangguan tumbuh kembang anak".

Setiap anak perlu mendapatkan stimulasi rutin sedini mungkin dan terus menerus pada setiap kesempatan. Kurangnya stimulasi dapat menyebabkan penyimpangan tumbuh kembang anak, bahkan gangguan menetap. Pembinaan tumbuh kembang anak secara komprehensif dan berkualitas di perlukan untuk mencapai tumbuh kembang yang optimal. Pembinaan ini meliputi kegiatan Stimulasi, Deteksi, Intervensi Dini Penyimpangan Tumbuh Kembang Anak ( SDIDTK). 
Perkembangan motorik pada anak Indonesia tergolong rendah, hasil penelitian Pusat Penelitian dan Pengembangan Gizi kemenkes RI tahun 2012 hasil survei Denver Development Screaning Test (DDST) II didapat prevalensi gangguan gangguan motorik halus dan kasar pada balita sebesar 25\%,atau setiap 2 dari 1.000 balita mengalami gangguan perkembangan motorik. Di negara negara maju seperti Amerika anak mulai berjalan rata-rata pada umur 11-12 bulan dan anak-anak di Eropa antara 12-13 bulan, sedangkan di Indonesia rata-rata 14 bulan (Kemenkes RI, 2012).

Berdasarkan hasil Riset Kesehatan Dasar (Riskesdas) 2013 menunjukkan bahwa persentase anak yang mengalami gangguan perkembangan motorik kasar di Indonesia sebesar $12,4 \%$ dan perkembangan motorik halus sebesar 9,8\%. Walaupun angka ini menurun dibandingkan hasil Riskesdas tahun 2010 gangguan perkembangan motorik kasar di Indonesia sebesar 8,8\% dan perkembangan motorik halus sebesar 6,2\% akan tetapi data tetapi menunjukkan bahwa anak yang mengalami gangguan perkembangan motorik masih menjadi masalah kesehatan masyarakat utama (Riskesdas, 2013).

Gangguan tumbuh kembang di DKI Jakarta berdasarkan hasil pelayanan Stimulasi Deteksi dan Intervensi Dini Tumbuh Kembang (SDIDTK) pada 500 anak dari lima Wilayah DKI Jakarta, ditemukan, 57 anak (11,9\%) mengalami kelainan tumbuh kembang. Kelainan tumbuh kembang yang paling banyak yaitu delayed development (pertumbuhan yang terlambat) 22 anak, kemudian 14 anak mengalami global delayed development, 10 anak gizi kurang, 7 anak Microcephali, dan 7 anak yang tidak mengalami kenaikan berat badan dalam beberapa bulan terakhir (Kemenkes, 2010).

Pertumbuhan dan perkembangan anak tergantung pada kualiatas rangsangan, dukungan dan pengasuhan anak di lingkungan atau keluarga, bila seorang anak tidak mendapatkan semua ini dapat mengakibatkan gagal tumbuh dan kembang. Menurut beberapa penelitian intervensi dini yang tepat dalam menangani faktor resiko, pertumbuhan, perkembangan kognitif dan sosial emosional dapat dilakukan dengan cara meningkatkan kesehatan, kesejahteraan dan kompetensi jangka panjang (WHO, 2014).

Perkembangan anak yang normal sangat tergantung pada lingkungan pengasuhan anak meliputi stimulasi dan interaksi ibu dan anak yang merupakan variabel utama yang mempengaruhi perkembangan anak. Peran ibu sangat bermanfaat bagi proses perkembangan anak secara keseluruhan karena orang tua dapat segera mengenali kelainan proses perkembangan anaknya dan sedini mungkin dengan memberikan stimulasi dan interaksi anak dalam aspek motorik, sensorik, kognitif, dan sosial. Perkembangan anak sangat dipengaruhi oleh pengetahuan tentang aspek-aspek perkembangan motorik anak. Ibu dengan pengetahuan baik akan untuk mempertahankan kehidupan fisik anak dan meningkatkan kesehatan anaknya, memfasilitasi anak untuk mengembangkan kemampuan sejalan dengan tahapan perkembangan dan mendorong peningkatan kemampuan berperilaku.

Kegiatan stimulasi, deteksi dan intervensi dini penyimpangan tumbuh kembang balita yang menyeluruh dan terkoordinasi diselenggarakan dalam bentuk kemitraan antara keluarga ( orang tua, pengasuh anak dan anggota keluarga), masyarakat ( kader, tokoh masyarakat, organisasi profesi, lembaga swadaya masyarakat) dengan tenaga profesional ( kesehatan, pendidikan dan sosial) akan meningkatkan kualitas tumbuh kembang anak usia dini dan kesiapan memasuki jenjang pendidikan formal. 
Berdasarkan latar belakang diatas, maka kami melakukan analisis perlunya dilakukan kegiatan pengabdian masyarakat dengan memberikan "Penyuluhan dan Simulasi Deteksi Dni terhadap pertumbuhan dan perkembangan anak usia dini dalam penanggulangan kegagalan pertumbuhan dan perkembangan anak di Pesantren Tapak Sunan Jakarta.

Kegiatan pengabdian masyarakat ini bertujuan untuk merubah sikap baik dari segi Kognitif, Afektif dan Konatif dari orang tua dan guru:

1. Kognitif

b. Orang Tua :

1. Dapat mengenali gangguan tumbuh kembang anak.

2. Dapat memantau tumbuh kembang anak secara rutin.

3. Dapat mendeteksi secara dini gangguan tumbuh kembang anak secara mandiri.

4. Mencatat pertumbuhan dan perkembangan anak secara rutin

c. Guru

1. Dapat mengetahui gangguan pertumbuhan dan perkembangan anak

2. Melaksanakan SDIDTK di lingkungan sekolah secara rutin

3. Mampu melakukan kolaborasi dengan tenaga kesehatan bila menemukan kegagalan tumbuh kembang

2. Afektif

a. Orang Tua :

1. Meningkatkan kepedulian orang tua terhadap tumbuh kembang anak

2. Dapat lebih memberikan waktu untuk memantau tumbuh kembang anak.

3. Dapat mengetahui pentingnya memantau tumbuh kembang anak

b. Guru

1. Dapat berperan aktif dalam membantu upaya program pemerintah

2. Menjadi garda terdepan membantu tenaga kesehatan dalam meningkatkan kualitas kesehatan anak.

3. Konatif

a. Orang Tua : 1. Dapat menjalani silaturahmi dengan guru

2. Memiliki kesempatan untuk bertemu dan berbagi informasi perkembangan dan pertumbuhan anak.

3. Diharapkan mampu melaksanakan deteksi dini dan mencatat secara mandiri tumbuh kembang anak.

b. Guru

1. Diharapkan mampu memotivasi orang tua untuk dapat be Peran aktif memantau tumbuh kembang anak. 


\section{Metode}

Kegiatan pengabdian masyarakat ini dilakukan atas dasar membantu program pemerintah khususnya wilayah Kota Administrasi Jakarta Timur dalam meningkatkan kepedulian keluarga dan sekolah dalam meningkatkan kualitas kesehatan anak khusus nya pertumbuhan dan perkembangan anak usia dini.

Langkah-langkah yang dilakukan dalam kegiatan ini :

1. Survey Lokasi Pengabdian

Pemilihan Iokasi pelaksanaan Pengabdian Kepada Masyarakat ditentukan berdasakan pada kepentingan aktual. Sebelum menentukan lokasi kegiatan terlebih dahulu dilakukan survey dan menanyakan prosedur pengurusan ijin di tempat tersebut

2. Instrumen untuk Pelaksanaan Kegiatan
a. Alat presentasi (Lap Top, LCD).
b. Leaflet
c. Spanduk
d. Kamera
e. Ballpoint
f. Lembar penilaian SDIDTK
g. Absensi Kehadiran

3. Jadwal Kegiatan

\begin{tabular}{clccc}
\hline No. & Uraian Kegiatan & Agustus & September & Oktober \\
\hline 1. & $\begin{array}{l}\text { Pengurusan } \\
\text { perijinan }\end{array}$ & $\mathrm{x}$ & & \\
2. & $\begin{array}{l}\text { Persiapan } \\
\text { pelaksanaan }\end{array}$ & $\mathrm{x}$ & & \\
3. & $\begin{array}{l}\text { Pelaksanaan } \\
\text { penyuluhan }\end{array}$ & & $\mathrm{x}$ & \\
4. & Pembuatan laporan & & & \\
\end{tabular}

Keterangan :

1. Pengurusan perijinan kepada ke tempat pelaksanaan dengan tujuan untuk kelancaran pelaksanaan pengabdian.

2. Persiapan pelaksanaan, meliputi persiapan materi penyuluhan, pemantapan materi penyuluhan dan kelengkapan pendukung penyuluhan.

3. Pelaksanaan pengabdian dilakukan di lokasi yang telah ditentukan. Metode yang digunakan dalam penyampaian materi :
a. Ceramah
Ceramah adalah penyajian informasi secara lisan baik formal maupun informal oleh pemateri
b. Simulasi cara melakukan Deteksi Dini Pertumbuhan dan Perkembangan Simulasi adalah memperagakan sesuatu dalam bentuk tiruan (imakan) yang mirip dengan keadaan yang sesungguhnya, dalam hal ini memperagakan cara memakai kondom.
c. Tanya Jawab 
Tanya Jawab adalah metode mengajar yang memungkinkan terjadinya komunikasi langsung yang bersifat two way traffic sebab pada saat yang sama terjadi dialog antara pemateri dan penerima materi. Sesi Tanya jawab ini digunakan untuk mengulang kembali materi yang sudah diberikan.

d. Doorprize

Sesi doorprize ini sekaligus digunakan untuk melakukan evaluasi terhadap kegiatan pengabdian masyarakat ini, 3 pertanyaan telah disiapkan dengan 3 hadiah bagi peserta yang dapat menjawab pertanyaan.

4. Pembuatan laporan dilakukan oleh Tim setelah selesai pelaksanaan pengabdian.

\section{Hasil dan Pembahasan}

Kegiatan pengabdian masyarakat ini dilakukan Hari minggu tanggal 25 Mei 2019 bertempat di PAUD Pesantren Tapak Sunan Jakarta Timur, dimulai dari pukul 09.00 WIB sampai pukul 11.00 WIB. Jumlah peserta kegiatan penyuluhan tentang deteksi dini pertumbuhan dan perkembangan anak usia dini dalam penanggulangan gangguan tumbuh kembang anak adalah sebanyak 27 peserta, mulai dari awal kegiatan sampai berakhirnya kegiatan peserta tidak ada yang meninggalkan ruangan dan mereka mengatakan kegiatan ini sangat bermanfaat untuk menambah pengetahuan dan kewaspadaan mereka terhadap bahaya gangguan pertumbuha dan perkembangan anak.

\section{Kesimpulan}

Kegiatan pengabdian masyarakat ini terlaksana dengan baik dan lancar sesuai tujuan dari pengabdian masyarakat ini, semua peserta yang hadir mampu mempraktekan cara mendeteksi pertumbuhan dan perkembangan anak mereka, dan tidak ditemukan gangguan dan perkembangan pada anak usia di ni di PAUD Pesantren Tapak Sunan Jakarta. Antusias dari peserta saat sesi tanya jawab dan sesi doorprize menunjukan keberhasilan dan ketercapaian dari kegiatan pengabdian masyarakat ini. Hal ini terbukti semua pertanyaan yang diberikan oleh pemateri dapat dijawab semua.

\section{Daftar Pustaka}

Adriana, Dian. (2011). Tumbuh Kembang dan Therapy Bermain pada anak. Jakarta: Salemba Medika.

Aisyah, Siti, dkk. (2010). Perkembangan dan Konsep Dasar Pengembangan Anak Usia. Dini. Jakarta: Universitas Terbuka.

Augusta. (2012). Pengertian Anak Usia Dini. Diambil dari http://infoini.com/pengertian anak usia dini

Hibama S Rahman. (2002). Konsep Dasar Pendidikan Anak Usia Dini. Yogyakarta: Galah.

Kemenkes RI. (2010). 11,9\% Anak Yang Mengikuti Sdidtk Mengalami Kelainan Tumbuh Kembang.

Online: 
https://www.kemkes.go.id/development/site/jkn/index.php?cid=1141\&id=119\%anak-yang-mengikuti-sdidtk-mengalami-kelainan-tumbuh-kembang.html.

Kemenkes RI. (2013). Riset Kesehatan Dasar. Jakarta : Badan Penelitian Dan Pengembangan Kesehatan Kementerian Kesehatan RI.

Kemenkes RI. (2012). Profil Kesehatan Indonesia. Jakarta : Kementerian Kesehatan RI.

Moersintowarti . (2002). Tumbuh Kembang Anak dan Remaja. Jakarta : Sagung.

Soetjiningsih. (2012). Tumbuh Kembang Anak. Jakarta: EGC. 